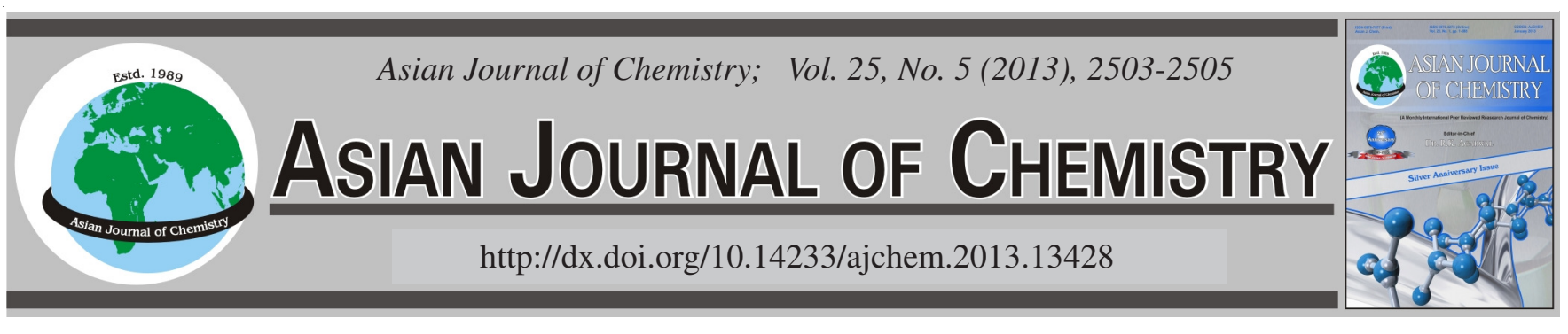

\title{
New Saponins from Timosaponin BIII by Acid Hydrolysis
}

\author{
ZhiYu Liu ${ }^{1,2}$, Weixin Jiang ${ }^{2}$, Bin WU ${ }^{1, *}$ and ChengGang HuAng ${ }^{1, *}$
}

${ }^{1}$ Shanghai Institute of Materia Medica Chinese Academy of Sciences, Shanghai 201203, P.R. China

${ }^{2}$ Harbin University of Commerce, Harbin 150076, P.R. China

*Corresponding author: Tel: + 8621 20231963; E-mail: cghsimm@126.com; wubin1031@ hotmail.com

(Received: 11 January 2012;

Accepted: 9 November 2012)

AJC-12389

\begin{abstract}
Timosaponin BIII (TBIII), a saponin isolated from the rhizome of Anemarrhena asphodeloides, exhibited potent antidepressive and anxiolytic activities in depressed mice. After administration of TBIII in rats, two main metabolites had been detected in the brain tissue, which had similar aglycone with TBIII and formed by elimination of two hexose moieties. In this study, we had hydrolyzed TBIII by some means and obtained 4 artificial steroidal saponins (three novel steroidal saponins: timosaponin BIII-a, timosaponin BIII-b, timosaponin BIII-c; and a known steroidal saponin: timosaponin BII-b) by the dilute-acid hydrolysis. Their structures were verified by means of mass spectrometry and nuclear magnetic resonance (NMR) spectral analyses.
\end{abstract}

Key Words: Rhizoma anemarrhenae, Steroidal saponin, Timosaponin BIII, Acid hydrolysis, NMR.

\section{INTRODUCTION}

Timosaponin BIII (also called anemarrhenasaponin IV or pseudoprototimosaponin AIII or timosaponin B) is a main activated compound of Rhizoma anemarrhenae ${ }^{1,2}$. TBIII had desirable hypoglycemic activity in streptozotocin-induced diabetic mice but showed no effects on glucose uptake and insulin release, which suggested that the hypoglycemic mechanism may be due to inhibition of hepatic gluconeogenesis and glycogenolysis ${ }^{2}$. In a activity study of timosaponin BIII, we found it had dramatically antidepressive and anxiolytic activities in depressed mice. After the intraperitoneal injection in rats, two main metabolites had been detected in the brain tissue, which formed by elimination of two hexose moieties and ring-opening reaction from the molecule of timosaponin BIII.

In the present study, we had performed dilute acid hydrolysis, Lewis acid catalyst and enzymatic hydrolysis of timosaponin BIII to find out the relationship between the structure and the antidepressive and anxiolytic activities. We had got 4 hydrolyzates from the sulphuric acid hydrolysis. The antidepressive and anxiolytic activities of these artificial products will be examined in future investigations.

\section{EXPERIMENTAL}

Timosaponin BIII was isolated from Rhizoma anemarrhenae, which was purchased from medicinal materials market of Shanghai (Shanghai City, China). HPLC grade acetonitrile was purchased from Dikma Company
(Dikma, USA). Other reagents used are of analytical grade (Sinopharm Chemical Reagent Co. Ltd., China).

Optical rotations were measured with a Perkin-Elmer 343 polarimeter. NMR spectra were measured on Varian Mercury400 (Varian, U.S.A), using Deuterium pyridine as solvents and TMS as an internal standard. HR-ESI-MS was carried out on a Micromass TOF Ultima (Micromass, U.K), the ionization mode was negative electrospray (ESI-). Semipreparative HPLC was performed on an Unimicro Technologies System (quaternary pump, China ) with a Grace Apollo $\mathrm{C}_{18}(10 \mathrm{~mm}$ i.d. $\times$ $250 \mathrm{~mm}$, ODS, $5 \mu \mathrm{m}$ ) semipreparative HPLC column, including an EasyGuard Kit $\mathrm{C}_{18}(4 \mathrm{~mm} \times 2 \mathrm{~mm})$ guard column; detector was UV.

A solution of timosaponin BIII (200 mg, $0.22 \mathrm{mmol})$ and sulfuric acid $(450 \mu \mathrm{L}, 8.28 \mathrm{mmol})$ in $\mathrm{CH}_{3} \mathrm{OH}-\mathrm{H}_{2} \mathrm{O}(150 \mathrm{~mL}$, 2:13). The mixture was stirred at $100{ }^{\circ} \mathrm{C}$ for $7 \mathrm{~h}$. The reaction solution was partitioned with $n$-butanol and the $n$-butanol solution was concentrated under reduced pressure to dryness. The residue was separated by semipreparative RP-HPLC using aqueous acetonitrile system (Fig. 1).

Chromatographic spectrometric conditions: The semipreparative HPLC was equipped with a reversed-phase column, including an $\mathrm{C}_{18}$ guard column. The column was maintained at $25^{\circ} \mathrm{C}$. The elution gradient for the semipreparative HPLC experiment was conducted using acetonitrile (A) and water (B). The UV detection wavelength was set at $205 \mathrm{~nm}$. The initial elution condition was $50 \%$ A (v/v), linearly changed to $100 \% \mathrm{~A}(\mathrm{v} / \mathrm{v})$ at $25 \mathrm{~min}$. 


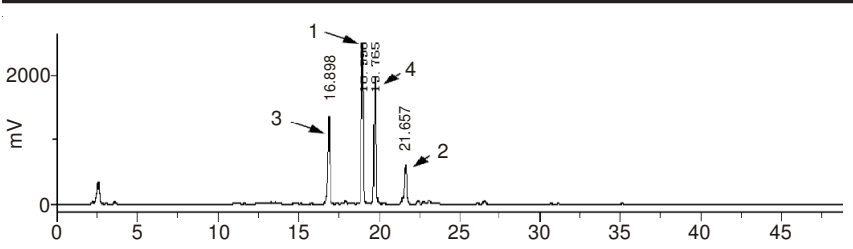

Fig. 1. HPLC profile of the reaction mixture of the hydrolysis of timosaponin BIII

\section{RESULTS AND DISCUSSION}

It gave 4 reaction products (Figs. 1 and 2$), \mathbf{1}\left(t_{\mathrm{R}} 18.99\right.$ $\min , 4.6 \mathrm{mg}), 2\left(\mathrm{t}_{\mathrm{R}} 21.66 \mathrm{~min}, 4.5 \mathrm{mg}\right), 3\left(\mathrm{t}_{\mathrm{R}} 16.90 \mathrm{~min}\right), 4.4$ $\mathrm{mg}$ and $4\left(\mathrm{t}_{\mathrm{R}} 19.77 \mathrm{~min}, 16.6 \mathrm{mg}\right)$. The quantitative yields of those compounds were $3.5,3.5,3.5$ and $12.6 \%$, respectively. We report herein upon the structural elucidation of three new compounds $(\mathbf{1}, \mathbf{2}, \mathbf{3})$ and of a known compound (4). The known steroidal saponin, timosaponin BII-b, was identified by a comparison of the observed $[\alpha]^{20}{ }_{\mathrm{D}},{ }^{1} \mathrm{H} \mathrm{NMR},{ }^{13} \mathrm{C}$ NMR, DEPT and HR-ESI-TOF-MS data with the literature values ${ }^{3}$.
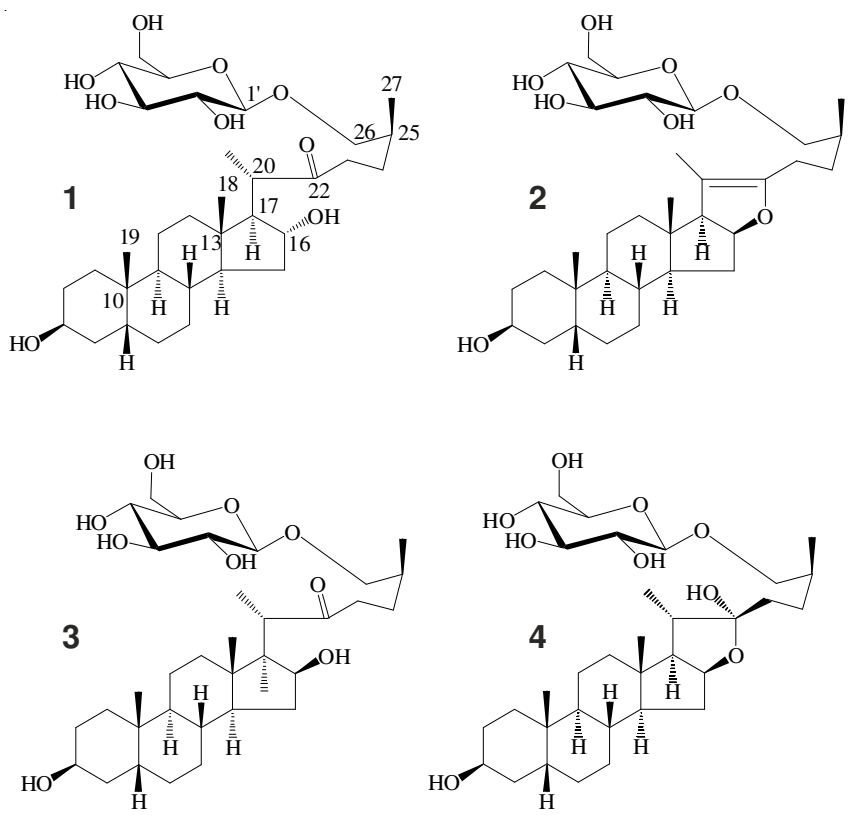

Fig. 2. Compounds 1, 2, 3 and $\mathbf{4}$ from hydrolysis of timosaponin BIII

Compound 1 was obtained as white amorphous powder, $[\alpha]^{20}{ }_{D}-46.0$ ( $c$ 0.05, pyridine). The molecular formula was determined as $\mathrm{C}_{33} \mathrm{H}_{56} \mathrm{O}_{9}$ by HR-ESI-MS $\left([\mathrm{M}+\mathrm{Na}]^{+} \mathrm{m} / \mathrm{z}\right.$ 619.3816; calcd. 619.3817). The ${ }^{13} \mathrm{C}$ NMR spectrum (Table1) of $\mathbf{1}$ displayed the presence of glycopyranosyl unit in addition to 26 carbon signals for the aglycone. The coupling constant of the anomeric proton at $\delta_{\mathrm{H}} 4.85(\mathrm{~J}=7.7 \mathrm{~Hz})$ showed a $\beta$-glycopyranoside. The 26 carbon atoms due to the aglycone were classified as 4 methyls, 12 methylenes, 14 methines and 3 quaternary carbon atoms using distortionless enhancement by polarization transfer (DEPT) spectrum analysis and ${ }^{13} \mathrm{C}$ NMR data. The ${ }^{1} \mathrm{H}$ and ${ }^{13} \mathrm{C}$ NMR spectra of the aglycone of $\mathbf{1}$ were closely resemble that of timosaponin $\mathrm{BIII}^{4}$, except for the appearance of the carbonyl carbon at $\delta_{\mathrm{C}} 214.86$ and the absence of one double bond. The connectivities of the molecular fragments were established by a heteronuclear multiple bond correlation experiment (HMBC), where the long-range correlations were observed between the protons of $\mathrm{H}-20\left(\delta_{\mathrm{H}}\right.$ $2.80), \mathrm{H}-21\left(\delta_{\mathrm{H}} 1.23\right)$ and $\mathrm{H}-23\left(\delta_{\mathrm{H}} 2.93,2.75\right)$ and the carbonyl carbon $\left(\delta_{\mathrm{C}} 214.86\right)$, whereas the protons of $\mathrm{H}-17\left(\delta_{\mathrm{H}} 1.90\right)$ and the oxygenated carbon $\left(\delta_{\mathrm{C}} 75.93\right)$, indicating that the carbonyl was located at C-22 and hydroxyl was placed at $\mathrm{C}-16$. This experiment also clarified the site of glycosidation showing a long-range correlation between the anomeric proton of glucose at $\delta_{\mathrm{H}} 4.85\left(\mathrm{H}-1^{\prime}\right)$ and the oxygenated carbon atom at $\delta_{\mathrm{C}} 75.19(\mathrm{C}-26)$. The stereochemistry of 1 was determined from the coupling pattern in the ${ }^{1} \mathrm{H}$ NMR spectrum and detailed analysis of rotation frame overhauser effect spectroscopy (ROESY) data. The ROE cross-peaks of significant intensity between the $\mathrm{H}-18$ at $\delta 0.71$ and the $\mathrm{H}-16$ at $\delta 4.29$ indicated that $16-\mathrm{OH}$ was a configuration. The cis-configuration between ring $\mathrm{A}$ and $\mathrm{B}$ was confirmed from the ROESY correlation of H-5 with H-19. The other significant ROESY correlations were shown on Fig. 3. Therefore, the structure of 1 was elucidated as shown and named timosaponin BIII-a, which had not previously been reported form natural sources or synthesis.

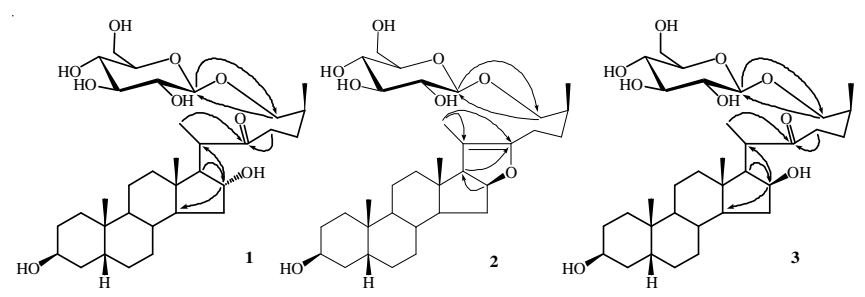

Fig. 3. Key HMBC of 1, 2 and 3

Compound 2 was isolated as white amorphous powder, $[\alpha]^{20}{ }^{2}-66.0$ ( $c 0.05$, pyridine), had a molecular formula of $\mathrm{C}_{33} \mathrm{H}_{55} \mathrm{O}_{8}$ by the positive ion HR-ESI-TOF-MS (Found $\mathrm{m} / \mathrm{z}$ : $601.3713[\mathrm{M}+\mathrm{Na}]^{+}$; calcd. for $\mathrm{C}_{33} \mathrm{H}_{55} \mathrm{O}_{8} \mathrm{Na}$ : 601.3711). The ${ }^{13} \mathrm{C} \mathrm{NMR}$ spectrum and DEPT experiment showed the presence of 4 methyls, 12 methylenes, 13 methines and 4 quarternary carbons. The presence of a b-glycopyranosyl moiety was determined by the anomeric proton at $\delta_{\mathrm{H}} 4.87(\mathrm{~J}=7.7 \mathrm{~Hz})$ and the carbon signal at $\delta_{\mathrm{C}} 105.19$. Its NMR spectral data were very similar to those of timosaponin $\mathrm{BIII}^{4}$ indicating the same basic skeleton for 2 . In the HMBC spectra, long-range correlations were observed from $\delta_{\mathrm{H}} 4.87\left(\mathrm{H}-1^{\prime}\right)$ to $\delta_{\mathrm{C}} 75.22(\mathrm{C}-26)$ and vice veisa. Accordingly, the structure of $\mathbf{2}$ was elucidated as shown and named timosaponin BIII-b, which also had not previously been reported form natural sources or synthesis.

Compound 3 was a white amorphous powder, $[\alpha]^{20}{ }_{D}-36.0$ (c 0.05 , pyridine). It showed a molecular formula of $\mathrm{C}_{33} \mathrm{H}_{56} \mathrm{O}_{9}$, as established by HR-ESI-TOF-MS (Found $m / z$ : 619.3815 $[\mathrm{M}+\mathrm{Na}]^{+}$; calcd. for $\left.\mathrm{C}_{33} \mathrm{H}_{56} \mathrm{O}_{9} \mathrm{Na}: 619.3817\right)$. Its NMR spectral data were very similar to those of $\mathbf{1}$ indicating the same basic skeleton for 3. Its ROESY spectrum were closely resemble that of $\mathbf{1}$, except for the absence of the correlation between the $\mathrm{H}-18$ at $\delta 0.76$ and the $\mathrm{H}-16$ at $\delta 4.09$. It indicated that $\mathbf{1}$ and $\mathbf{3}$ were epimers and $16-\mathrm{OH}$ of $\mathbf{3}$ was $\beta$ configuration. The other significant ROESY correlations were shown on Fig. 4. Therefore, the structure of $\mathbf{3}$ was elucidated as shown and named timosaponin BIII-c, which had not previously been reported form natural sources or synthesis. 


\begin{tabular}{|c|c|c|c|c|c|c|c|c|}
\hline & NMR & PECTR & DATA FOR $\mathbf{1}, \mathbf{2}, \mathbf{3}$ & $\begin{array}{r}\text { TA } \\
\mathrm{D} 4 \mathrm{IN} \mathrm{P}\end{array}$ & IDINE- $d_{5}(\delta \mathrm{ppm})$ & $400 \mathrm{M}$ & $\left.{ }^{3} \mathrm{C}: 100 \mathrm{MHz}\right)$ & \\
\hline & 1 & & 2 & & 3 & & 4 & \\
\hline No. & $\delta_{\mathrm{H}}(\mathrm{J}$ in $\mathrm{Hz})$ & $\delta_{\mathrm{C}}$ & $\delta_{\mathrm{H}}(\mathrm{J}$ in $\mathrm{Hz})$ & $\delta_{\mathrm{C}}$ & $\delta_{\mathrm{H}}(\mathrm{J}$ in $\mathrm{Hz})$ & $\delta_{\mathrm{C}}$ & $\delta_{\mathrm{H}}(\mathrm{J}$ in $\mathrm{Hz})$ & $\delta_{\mathrm{C}}$ \\
\hline 1 & $1.58(\mathrm{~m}), 1.93(\mathrm{~m})$ & 30.47 & $1.89(\mathrm{~m})$ & 30.64 & $1.52(\mathrm{~m}), 1.88(\mathrm{~m})$ & 30.52 & $1.73(\mathrm{~m}), 1.61(\mathrm{~m})$ & 28.61 \\
\hline 2 & $1.91(\mathrm{~m}), 1.33(\mathrm{~m})$ & 27.12 & $1.94(\mathrm{~m}), 1.33(\mathrm{~m})$ & 27.14 & $1.92(\mathrm{~m}), 1.19(\mathrm{~m})$ & 27.19 & $1.88(\mathrm{~m}), 1.14(\mathrm{~m})$ & 27.16 \\
\hline 3 & $4.42(\mathrm{~m})$ & 66.06 & $4.42(\mathrm{~m})$ & 66.07 & $4.41(\mathrm{~m})$ & 66.07 & $4.38(\mathrm{~m})$ & 66.01 \\
\hline 4 & $1.84(\mathrm{~m}), 1.67(\mathrm{~m})$ & 36.95 & $1.63(\mathrm{~m}), 1.55(\mathrm{~m})$ & 34.41 & $1.92(\mathrm{~m}), 1.75(\mathrm{~m})$ & 37.54 & $1.85(\mathrm{~m}), 1.54(\mathrm{~m})$ & 30.62 \\
\hline 5 & $1.71(\mathrm{~m})$ & 37.00 & $2.17(\mathrm{~m})$ & 37.04 & $2.17(\mathrm{~m})$ & 37.08 & $1.96(\mathrm{~m})$ & 37.03 \\
\hline 6 & $1.32(\mathrm{~m}), 1.18(\mathrm{~m})$ & 26.58 & $1.34(\mathrm{~m}), 1.18(\mathrm{~m})$ & 26.97 & $1.39(\mathrm{~m}), 1.19(\mathrm{~m})$ & 26.65 & $1.54(\mathrm{~m})$ & \\
\hline 7 & $1.75(\mathrm{~m}), 1.63(\mathrm{~m})$ & 28.59 & $1.76(\mathrm{~m}), 1.59(\mathrm{~m})$ & 28.65 & $1.78(\mathrm{~m}), 1.62(\mathrm{~m})$ & 28.61 & $1.33(\mathrm{~m})$ & 26.87 \\
\hline 8 & $1.36(\mathrm{~m})$ & 35.37 & $1.52(\mathrm{~m})$ & 35.27 & $1.38(\mathrm{~m})$ & 35.45 & $1.04(\mathrm{~m})$ & 35.59 \\
\hline 9 & $1.84(\mathrm{~m})$ & 40.00 & $1.80(\mathrm{~m})$ & 40.12 & $1.39(\mathrm{~m})$ & 40.08 & $1.35(\mathrm{~m})$ & 40.10 \\
\hline 10 & - & 35.42 & - & 35.57 & - & 35.49 & - & 35.59 \\
\hline 11 & $1.39(\mathrm{~m}), 1.23(\mathrm{~m})$ & 21.00 & $1.79(\mathrm{~m}), 1.40(\mathrm{~m})$ & 21.38 & $1.35(\mathrm{~m}), 1.15(\mathrm{~m})$ & 20.97 & $1.42(\mathrm{~m}), 1.29(\mathrm{~m})$ & 21.22 \\
\hline 12 & $1.38(\mathrm{~m}), 1.30(\mathrm{~m})$ & 40.39 & $1.39(\mathrm{~m}), 1.27(\mathrm{~m})$ & 40.15 & $1.58(\mathrm{~m}), 1.30(\mathrm{~m})$ & 39.59 & $1.79(\mathrm{~m}), 1.18(\mathrm{~m})$ & 40.47 \\
\hline 13 & - & 44.49 & - & 43.88 & - & 44.01 & - & 41.26 \\
\hline 14 & $1.55(\mathrm{~m})$ & 53.71 & $1.49(\mathrm{~m})$ & 54.82 & $1.62(\mathrm{~m})$ & 53.36 & $1.14(\mathrm{~m})$ & 56.48 \\
\hline 15 & $2.01(\mathrm{~m}), 1.56(\mathrm{~m})$ & 34.32 & $1.89(\mathrm{~m}), 1.51(\mathrm{~m})$ & 31.39 & $2.0(\mathrm{~m}), 1.60(\mathrm{~m})$ & 34.37 & $2.01(\mathrm{~m}), 1.41(\mathrm{~m})$ & 32.43 \\
\hline 16 & $4.29(\mathrm{~m})$ & 75.93 & $4.88(\mathrm{~m})$ & 84.59 & $4.09(\mathrm{~m})$ & 75.22 & $4.58(\mathrm{~m})$ & 81.22 \\
\hline 17 & $1.90(\mathrm{~d}, 3.2)$ & 63.39 & $2.55(\mathrm{~d}, 10.1)$ & 64.68 & $2.23(\mathrm{dd}, 6.4,10.4)$ & 62.17 & $2.01(\mathrm{~m})$ & 64.02 \\
\hline 18 & $0.71(\mathrm{~s})$ & 13.65 & $0.75(\mathrm{~s})$ & 14.45 & $0.76(\mathrm{~s})$ & 14.93 & $0.94(\mathrm{~s})$ & 16.76 \\
\hline 19 & $1.03(\mathrm{~s})$ & 24.19 & $1.05(\mathrm{~s})$ & 24.26 & $1.01(\mathrm{~s})$ & 24.24 & $1.04(\mathrm{~s})$ & 24.26 \\
\hline 20 & $2.80(\mathrm{~m})$ & 49.34 & - & 103.59 & $2.84(\mathrm{dq}, 6.6,10.4)$ & 47.09 & $2.25(\mathrm{~m})$ & 40.66 \\
\hline 21 & $1.23(\mathrm{~d}, 6.7)$ & 16.78 & $1.67(\mathrm{~s})$ & 11.83 & $1.49(\mathrm{~d}, 6.95)$ & 17.28 & $1.37(\mathrm{~m})$ & 16.48 \\
\hline 22 & - & 214.86 & - & 152.38 & - & 214.63 & - & 110.65 \\
\hline 23 & $2.93(\mathrm{~m}), 2.75(\mathrm{~m})$ & 38.89 & $1.56(\mathrm{~m})$ & 34.41 & $2.76(\mathrm{~m})$ & 38.91 & $2.09(\mathrm{~m})$ & 37.15 \\
\hline 24 & $2.06(\mathrm{~m}), 1.91(\mathrm{~m})$ & 27.92 & $2.23(\mathrm{~m}), 1.04(\mathrm{~m})$ & 23.62 & $2.06(\mathrm{~m}), 1.92(\mathrm{~m})$ & 27.92 & $2.07(\mathrm{~m}), 1.69(\mathrm{~m})$ & 28.33 \\
\hline 25 & $2.01(\mathrm{~m})$ & 33.56 & $1.63(\mathrm{~m})$ & 33.68 & $2.01(\mathrm{~m})$ & 33.56 & $1.92(\mathrm{~m})$ & 34.42 \\
\hline 26 & $\begin{array}{l}4.07(\mathrm{~m}, 6.5), \\
3.52(\mathrm{dd}, 9.4)\end{array}$ & 75.19 & $\begin{array}{l}4.11(\mathrm{dd}, 5.7,9.2) \\
3.52(\mathrm{dd}, 6.9,9.2)\end{array}$ & 75.22 & $\begin{array}{c}4.33(\mathrm{~m}), \\
3.56(\mathrm{dd}, 6.3,9.5)\end{array}$ & 75.01 & $\begin{array}{l}4.08(\mathrm{~m}), \\
3.48(\mathrm{~m})\end{array}$ & 75.38 \\
\hline 27 & $1.02(\mathrm{~d}, 7.4)$ & 17.44 & $1.08(\mathrm{~m})$ & 17.16 & $1.04(\mathrm{~d}, 6.6)$ & 17.41 & $1.07(\mathrm{~d})$ & 17.44 \\
\hline $1^{\prime}$ & $4.85(\mathrm{~d}, 7.7)$ & 105.02 & $4.87(\mathrm{~m}, 7.7)$ & 105.19 & $4.88(\mathrm{~d}, 7.75)$ & 105.10 & 4.84 (d) & 105.10 \\
\hline $2^{\prime}$ & $4.06(\mathrm{~m})$ & 75.21 & $4.07(\mathrm{~m})$ & 75.21 & $4.09(\mathrm{~m})$ & 74.95 & $4.01(\mathrm{~m})$ & 75.21 \\
\hline $3^{\prime}$ & $4.28(\mathrm{~m})$ & 78.50 & $4.28(\mathrm{~m})$ & 78.53 & $4.29(\mathrm{~m})$ & 78.58 & $4.23(\mathrm{~m})$ & 78.59 \\
\hline $4^{\prime}$ & $4.27(\mathrm{~m})$ & 71.64 & $4.28(\mathrm{~m})$ & 71.68 & $4.28(\mathrm{~m})$ & 71.70 & $4.23(\mathrm{~m})$ & 71.65 \\
\hline $5^{\prime}$ & $3.98(\mathrm{~m})$ & 78.58 & $4.00(\mathrm{~m})$ & 78.60 & $4.01(\mathrm{~m})$ & 78.63 & $3.94(\mathrm{~m})$ & 78.49 \\
\hline $6^{\prime}$ & $4.59(\mathrm{~m}), 4.42(\mathrm{~m})$ & 62.75 & $4.59(\mathrm{~m}), 4.43(\mathrm{~m})$ & 62.82 & $\begin{array}{c}4.61 \text { (brd, 11.6), } \\
4.44(\mathrm{~m})\end{array}$ & 62.86 & $4.55(\mathrm{~m}), 4.39(\mathrm{~m})$ & 62.77 \\
\hline
\end{tabular}
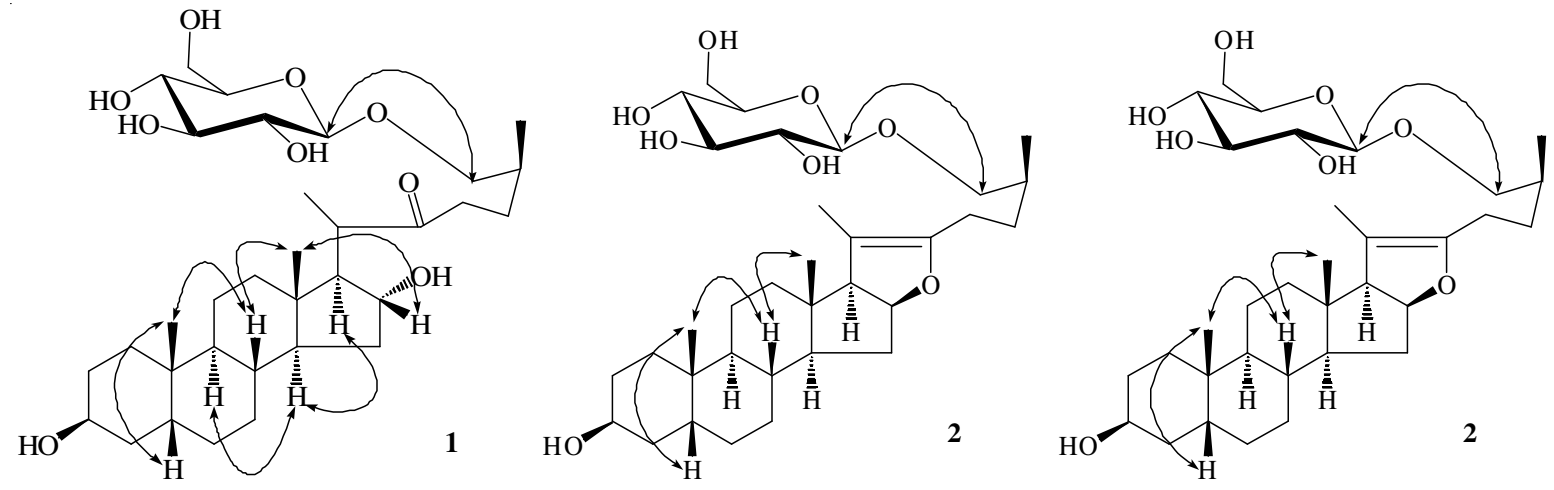

Fig. 4. Key ROESY correlations of $\mathbf{1}, \mathbf{2}$ and $\mathbf{3}$

\section{ACKNOWLEDGEMENTS}

The authors thank the National Science \& Technology Major Project Key New Drug Creation and Manufacturing Program, China (Nos. 2009ZX09301-001, 2009ZX09102121, 2009ZX09501-030) and 2012ZX09301001-001) and the Key and General Programs of National Natural Science Foundation of China (Nos. 81030065 and 81274055) for financial support of this work.

\section{REFERENCES}

1. S. Saito, S. Nagase and K. Ichinose, Chem. Pharm. Bull., 42, 2342 (1994).

2. N. Nakashima, I. Kimura and M. Kimura, Nat. J. Prod., 56, 345 (1993).

3. W.B. Zhou, B. Feng and H.Z. Huang, Asian Nat. Prod. Res., 12, 955 (2010).

4. J. Bian, S.X. Xu and S. Huang, J. Shenyang Pharm. Univ., 13, 34 (1996). 